\title{
A NEW CYRTOCHILUM (ORCHIDACEAE: ONCIDIINAE) FROM SIERRA NEVADA DE SANTA MARTA IN COLOMBIA
}

\author{
STIG DALSTRÖM \\ 2304 Ringling Boulevard, unit 119, Sarasota FL 34237, U.S.A. \\ Lankester Botanical Garden, University of Costa Rica, Cartago, Costa Rica \\ and National Biodiversity Centre, Serbithang, Bhutan \\ stigdalstrom@juno.com
}

\begin{abstract}
A new species of Cyrtochilum from the isolated region of Sierra Nevada de Santa Marta in Colombia is described and illustrated, and compared with similar species. It is distinguished from other Cyrtochilum species by the violet color of the sepals and petals, in combination with the pandurate lip lamina with a large and protruding nose-like central callus keel.
\end{abstract}

Key words: Cyrtochilum, Orchidaceae, Oncidiinae, new species, Colombia, Santa Marta, Sierra Nevada, taxonomy

During a past visit to the Marie Selby Botanical Gardens (MSBG) in Sarasota, Florida, Mariano Ospina brought a large number of dried orchid specimens for identification purposes, mainly from the National Herbarium of Colombia (COL) in Bogotá. The herbarium batch consisted of species that today are placed in many different genera, including Cyrtochilum Kunth, Erycina Lindl., Heteranthocidium Szlach., Mytnik \& Romowicz, Oncidium Sw., Otoglossum (Schltr.) Garay \& Dunst., and Trichocentrum Poepp. \& Endl. (the names of the genera vary depending on which taxonomist is consulted). During this project, which was a collaboration between Ospina and MSBG, I had the opportunity to analyze the material and encountered a Cyrtochilum species that was unknown to me. A drawing was made at the time of this unusual looking and most certainly quite attractive species. Eventually it became clear that it represented an undescribed species, which is described herein.

\section{Cyrtochilum violaceum Dalström, sp. nov.}

TYPE: Colombia, Magdalena, Sierra Nevada de Sta. Marta, Transecto del Alto Rio Buritaca, Cuchilla at 2900 m, Lev. 29. Proyecto Desarrollo, 5 August 1977; R. Jaramillo M. et al. 5366 (holotype, COL). FIg. 1.

Diagnosis: Cyrtochilum violaceum is distinguished from other Cyrtochilum species by the violet color of the sepals and petals, in combination with a pandurate lip lamina with a large and protruding nose-like central callus keel, which is similar to the not closely related Oncidium mantense Dodson \& R.Estrada. Cyrtochilum violaceum differs from the similarly colored and closely related Cyrtochilum undulatum Kunth [syn: $C$. orgyale (Rchb.f. \& Warsc.) Kraenzl.] by the pandurate lip lamina, the cleft and distinct frontal angles of the stout column, and the pair of digitate or narrowly clavate wings on each side below the stigmatic surface, versus a triangular lip lamina, and a more slender and sigmoid column of the latter species with short angular knobs only, or without wings altogether.

Epiphytic herb. Pseudobulbs caespitose to creeping on a bracteate rhizome, ovoid, $c a .5 \times 2$ $\mathrm{cm}$, bifoliate, surrounded basally by 7 to 8 distichous sheaths, the uppermost foliaceous. Leaves subpetiolate, conduplicate, elliptic to slightly obovate, narrowly acute, $c a .16-17 \times 2 \mathrm{~cm}$. Inflorescence axillary from the uppermost sheath, an erect to arching, to $c a$. 70 $\mathrm{cm}$ long loosely flexuous panicle, with widely spaced 3 to 4 flexuous, 2- to 4-flowered side-branches (up to 6 or more flowers on 7 branches have been noted on an additional specimen). Floral bracts large and conspicous, involute and cucullate, ca. $10-15 \mathrm{~mm}$ long. Pedicel with ovary 20-25 mm long. Flowers apparently open and stellate; dorsal sepal violet, shortly spathulate, then truncate and broadly ovate to elliptic laminate, obtuse, slightly undulate, $c a$. 

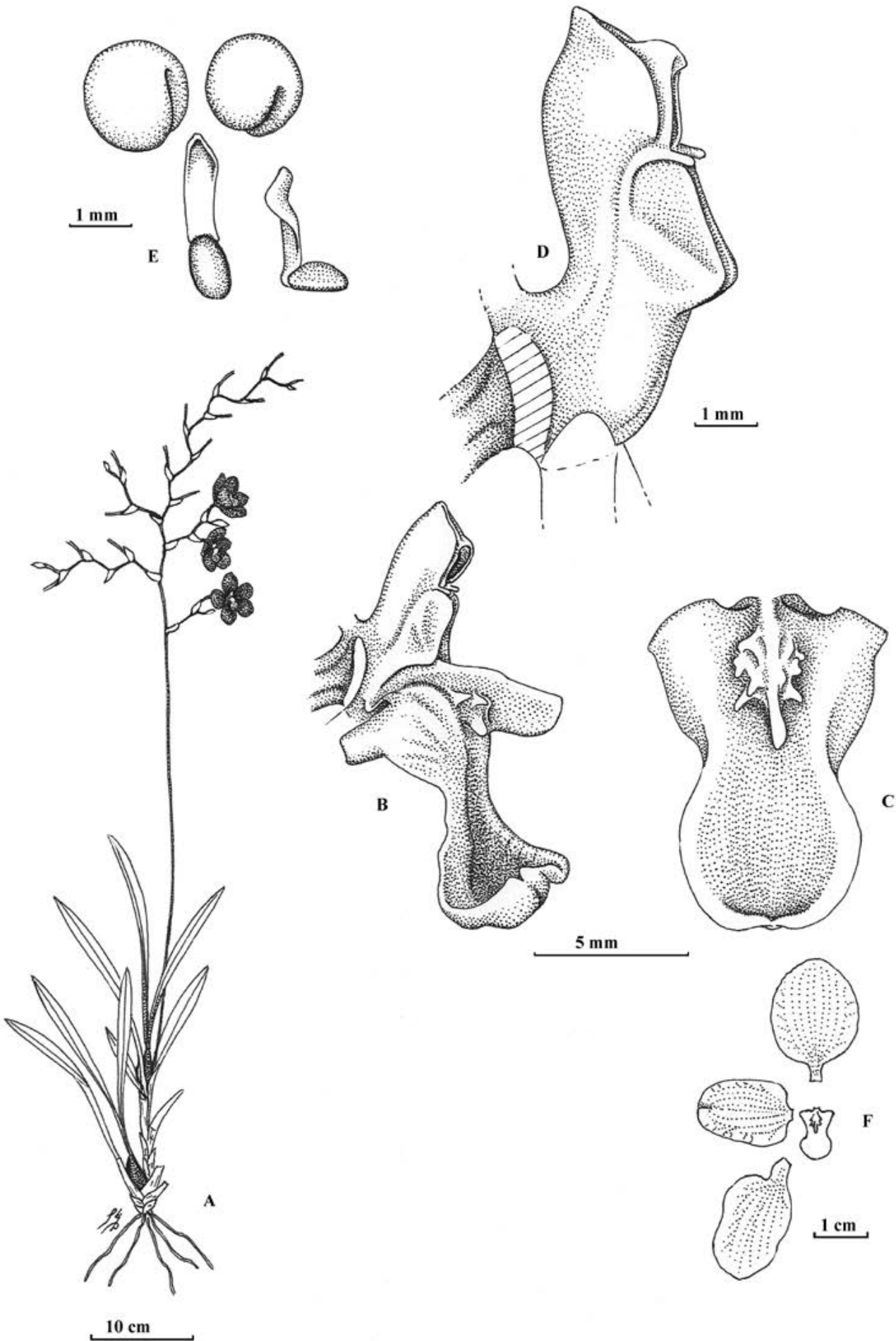

FIgURE 1. Cyrtochilum violaceum. A. Plant habit. B. Column and lip lateral view. C. Lip dorsal view. D. Column lateral view.

E. Pollinia and stipe. F. Flower dissected. Drawn from holotype by Stig Dalström. 
$25 \times 18 \mathrm{~mm}$; lateral sepals similar in color, slightly obliquely spathulate, then obliquely cordate, broadly and weakly pandurate laminate, obtuse, $c a .25 \times 15$ $\mathrm{mm}$; petals similar in color, almost sessile, truncate to cordate, then broadly ovate and rounded obtuse with a canaliculate acute, almost folded apex, $c a .20 \times 13$ $\mathrm{mm}$; lip rigidly attached to the base of the column and angled downwards, truncate to cordate, pandurate with obtuse triangular lateral lobes, and a rounded and slightly concave, weakly bilobed to minutely apiculate frontlobe, $c a .10 \times 8 \mathrm{~mm}$; callus yellow, of a fleshy denticulate structure emerging from the base and extending to almost half the length of the lamina, with several spreading lower lateral denticles and a dominating, projecting, laterally compressed, noselike central keel; anthercap not seen; pollinarium of two globose cleft pollinia on a $c a .2 \mathrm{~mm}$ long and narrow stipe on a pulvinate viscidium.

Paratype: Colombia, Magdalena, Sierra Nevada de Sta. Marta, Transecto del Alto Rio Buritaca, Cuchilla at $2700 \mathrm{~m}$, Lev. 27. Proyecto Desarrollo, 2 August 1977, R. Jaramillo M. et al. 5352 (COL).

Distribution: Sierra Nevada de Santa Marta, Colombia.

Etymology: Named in reference to the main color of the flower.

Cyrtochilum violaceum is so far only reported from the Sierra Nevada de Santa Marta region in northern Colombia. The poorly explored forests of this isolated mountain are likely to contain a large number of endemic species, both in the fauna and the flora. Several attractive orchid species have been described from there that are found nowhere else, such as Odontoglossum naevium Lindl., and $O$. nevadense. Rchb.f.

AcKNowledgment. I wish to thank Mariano Ospina for bringing the specimens to the US, and thus making them available to the author. I also wish to thank Wesley Higgins for reviewing and commenting on the manuscript. 